\title{
$\beta$-Carotene biotransformation to obtain aroma compounds
}

\author{
Biotransformação de $\beta$-caroteno para obtenção de compostos de aroma
}

\author{
Mariana $\mathrm{UENOJO}^{1 *}$, Glaucia Maria PASTORE ${ }^{1}$
}

\begin{abstract}
Carotenoids are important constituents of food due to their color and because their degradation products generate important volatile compounds in foods. Aroma compounds derived from carotenoids are widely distributed in nature, and they are precursors of many important aromas in foods such as fruits and in flowers as well. They present high aromatic potential and are therefore of great interest to the industries of aromas and fragrances. In this study, more than 300 previously isolated microorganisms with potential for biotransformation of $\beta$-carotene present in the culture medium were selected using the plate method; about 80 strains presented capacity to produce aroma compounds and 7 strains were selected by an untrained panel of tasters to generate aroma compounds. The $\beta$-ionone was the main compound produced by CS1 (34.0 mg. $\left.\mathrm{L}^{-1}\right)$ and CF9 (42.4 mg. $\left.\mathrm{L}^{-1}\right)$ microorganisms at 72 and 24 hours of fermentation, cultured with and without pre-inoculation, respectively. The $\beta$-damascone and pseudoionone were found in low concentrations, 1,1,6-trimethyl-1,2,3,4-tetrahydronaphthalen (TTN) was tentatively identified and other compounds such as apocarotenoids, apparently obtained from the cleavage of the central part of the carotenoid, were detected.

Keywords: carotenoids; biotransformation; $\beta$-carotene, $\beta$-ionone; aroma.
\end{abstract}

\section{Resumo}

Carotenoides são importantes constituintes de alimentos por sua coloração e por seus produtos de degradação gerarem compostos voláteis em alimentos. Compostos de aromas derivados de carotenoides estão distribuídos na natureza, constituem precursores de aromas importantes em alimentos como frutas e em flores. Apresentam alto potencial aromático e, por isso, são de grande interesse para as indústrias de aromas e fragrâncias. Neste trabalho, mais de 300 microrganismos foram selecionados pelo método da placa, de acordo com sua capacidade de degradar carotenoides presentes no meio de cultura. Cerca de 80 linhagens apresentaram capacidade de produção de aromas e 7 cepas apresentaram descritores e intensidades de aromas de interesse, segundo um painel não treinado de provadores, sendo selecionadas e submetidas à fermentação submersa para produção de compostos aromas derivados de $\beta$-caroteno. $\beta$-Ionona foi o principal produto obtido da degradação de $\beta$-caroteno, encontrado em maiores concentrações nas linhagens CS1 (34,0 mg.L.-1) e CF9 $\left(42,4\right.$ mg.L $\left.L^{-1}\right)$ em 72 e 24 horas de fermentação nos meios de cultura sem e com pré-inóculo, respectivamente. Os compostos $\beta$-damascona e pseudoionona foram encontrados em baixas concentrações, 1,1,6-trimetil-1,2,3,4-tetraidronaftaleno (TTN) foi tentativamente identificado e apocarotenoides, provavelmente obtidos da clivagem da parte central do carotenoide, foram detectados.

Palavras-chave: carotenoides; biotransformação; $\beta$-caroteno; $\beta$-ionona; aroma.

\section{Introduction}

Carotenoids are important constituents of foods. Since their color and degradation products lead to the formation of aroma compounds, those compounds play an important role in sensory properties of food products. Their structure and related physicochemical properties represent important functions and actions of all living organisms in nature (WACHÉ et al., 2003).

Aroma is one of the most significant and decisive parameters of quality in the acceptance of a product. Aroma compounds are present in foods as free volatiles, and they also form complexes with non-volatile precursors such as cystein sulfoxide, thioglycosides, glycosides, carotenoids, and cinnamic acid derivatives (SOLÍS-SOLÍS et al., 2007).
The quality of fruit is determined by a series of events that affect taste, aroma, texture, color, nutritional value, and shelf life. Among the many products that are biosynthesized during the development of fruit and that affect its quality, the terpenes have a crucial role for they consist of pigments, such as carotenoids and aroma compounds such as mono-, sesquiterpenes and noroisoprenoid compounds (IBDAH et al., 2006).

C-13 noroisoprenoids compounds, such as $\beta$-ionone, $\beta$-damascone, $\beta$-damascenone, pseudoionone and TTN (Figure 1) are important aroma compounds related to carotenoids degradation (WINTERHALTER; ROUSEFF, 2002; SOMMERBURG et al., 2003; BALDERMANN; NAIM; FLEISCHMANN, 2005). The $\beta$-ionone is a compound derived

Recebido para publicação em 12/11/2008

Aceito para publicação em 16/5/2009 (003954)

${ }^{1}$ Laboratório de Bioaromas, Departamento de Ciência de Alimentos, Faculdade de Engenharia de Alimentos, Universidade Estadual de Campinas - UNICAMP,

Rua Monteiro Lobato, n. 80, CP 6121, CEP 13083-862, Campinas - SP, Brasil, E-mail: mariuenojo@yahoo.com.br, glaupast@fea.unicamp.br

${ }^{*}$ A quem a correspondência deve ser enviada 
from the degradation of $\beta$-carotene and presents intense floral and fruity notes. It is present in low concentrations in plant tissues, which makes its extraction costly and laborious leading to the development of other processes able to produce it (WACHÉ; BOSSER-DERATULD; BELIN, 2006).

Due to the increasing demand for natural products and to the problems associated with organic synthesis, the industries of aroma and fragrances are actively searching for new aromas as well as new technologies for the production of natural compounds. One of the emerging fields for the production of these compounds is that of biotechnology, especially in the use of enzymes and microorganisms for biocatalysis (SHIMONI et al., 2003). Biotransformation of carotenoids seems to be a reasonable alternative to produce flavor compounds since these compounds are considered 'natural' ingredients (UENOJO; MARÓSTICA JÚNIOR; PASTORE, 2007).

The purpose of this study was to observe the carotenoids degradation and the formation of volatile aroma compounds obtained from the biotransformation of $\beta$-carotene in submerged fermentation by microorganisms that were previously isolated and selected.

\section{Material and methods}

\subsection{General}

Due to $\beta$-carotene sensitivity to light and heat, the solutions were prepared right before use and sterilized by filtration (Millipore $0.22 \mu \mathrm{m}$, Billerica, USA).

\subsection{Materials}

The constituents of the standard nutrient solution, Tween 80 and solvents (dichloromethane, ether, and hexane) were obtained from Merck (Darmstadt, Germany), $\beta$-carotene from Sigma (St. Louis, USA), $\beta$-ionone from Acros Organics (New Jersey, USA), $\beta$-damascone, pseudoionone from Fluka (Buchs, Switzerland), and anhydrous ethanol from J. T. Baker (Phillipsburg, USA).

\subsection{Microorganisms}

The microorganisms were selected from the culture collection of the Laboratory of Bioaromas of the School of Food Engineering, Unicamp (State University of Campinas, Brazil). The strains were cultured and maintained at $4{ }^{\circ} \mathrm{C}$ for periodical replications on Potato Dextrose Agar (PDA).

\subsection{Selection of microorganisms on carotene agar plates}

The previously isolated microorganisms were selected by the plate method regarding their potential to degrade the $\beta$-carotene present in the culture medium. Briefly, the solution of $\beta$-carotene was prepared with $125 \mathrm{mg}$ of $\beta$-carotene dispersed in $12.5 \mathrm{~g}$ of Tween 80 , dissolved in $200 \mathrm{~mL}$ of dichloromethane, and dispersed in standard nutrient solution containing $2 \%$ agar (ZORN et al., 2003a). Tween 80 (polyoxyethylene sorbitan monooleate) is a surfactant to aid $\beta$-carotene dissolution.

After the medium cool down, the microorganisms were inoculated and incubated at $30^{\circ} \mathrm{C}$ until satisfactory development of colonies, in which the presence of degradation halo around the colony halo was observed.

\subsection{Selection of microorganisms to produce the aroma compounds}

To verify the capacity of aroma compounds production, the microorganisms selected on carotene agar plates were submitted at fermentation for 72 hours in $20 \mathrm{~mL}$ of standard nutrient solution (ZORN et al., 2003a) supplemented with $\beta$-carotene $(0.1 \% \mathrm{w} / \mathrm{v})$ dissolved in $50 \%$ ethanol and sterilized by filtration.

The strains were selected by a non-trained panel composed by 5 members, who evaluated the aroma and intensities according to an aroma intensities scale (Chart 1).

\subsection{Biotransformation of $\beta$-carotene in cultures of submerged fermentation}

The selected aroma producers microorganisms were inoculated in $20 \mathrm{~mL}$ of standard nutrient solution (ZORN et al., 2003a) supplemented with a solution of $\beta$-carotene (Sigma, St. Louis, USA) $0.1 \%(\mathrm{w} / \mathrm{v})$ dissolved in $50 \%$ ethanol (J. T. Baker, Phillipsburg, USA) sterilized by filtration (SÁNCHEZCONTRERAS; JIMÉNEZ; SANCHES, 2000; MALDONADOROBLEDO, et al., 2003; RODRÍGUEZ-BUSTAMANTE et al., 2005).

Chart 1. Scale of aroma intensities.

\begin{tabular}{|ll|}
\hline Scale & Intensity of aroma \\
\hline++++ & Very intensive aroma \\
+++ & Intensive aroma \\
++ & Moderate aroma \\
+ & Weak aroma \\
- & No aroma \\
\hline
\end{tabular}<smiles>CC(=O)/C=C/C1=C(C)CCCC1(C)C</smiles>

$\beta$-ionone

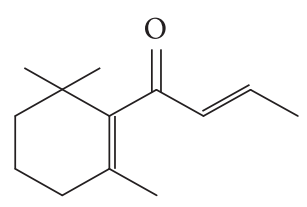

$\beta$-damascone<smiles>C/C=C/C(=O)C1=C(C)C=CCC1(C)C</smiles>

$\beta$-damascenone<smiles>CC(=O)/C=C/C=C(\C)CCC=C(C)C</smiles>

Pseudoionone<smiles>Cc1ccc2c(c1)CCCC2(C)C</smiles>

TTN

Figure 1. Aroma volatile compounds formed by the biodegradation of $\beta$-carotene. 
With regard to the strains cultivated without preinoculation, the microorganisms were inoculated in standard nutrient solution supplemented with $\beta$-carotene solution and incubated in a rotary shaker (New Brunswick Scientific, INNOVA 4335 model, Hertfordshire, United Kingdom) at $25^{\circ} \mathrm{C}$, $150 \mathrm{rpm}$ for 120 hours.

With regard to the strains cultivated with pre-inoculation, the microorganisms were inoculated in standard nutrient solution and incubated in rotary shaker at $25^{\circ} \mathrm{C}, 150 \mathrm{rpm}$ for 24 hours. After the incubation period, a solution of $\beta$-carotene was added. Afterwards, the cultures were incubated in a rotary shaker at $150 \mathrm{rpm}$ and $25^{\circ} \mathrm{C}$ for 120 hours.

\subsection{Sample treatments}

The products obtained extracellularly were quantified. The supernatant was extracted with $2 \mathrm{~mL}$ of ether:hexane (1:1). The organic extracts were separated from the aqueous stages and concentrated with flow of N2 gas (SÁNCHEZ-CONTRERAS; JIMÉNEZ; SANCHES, 2000; MALDONADO-ROBLEDO et al., 2003; RODRÍGUEZ-BUSTAMANTE et al., 2005). $1 \mu \mathrm{L}$ of the organic extract for splitless injection was used in the gas chromatograph.

\subsection{Gas chromatography - FID}

The chromatographic analyses were performed on a gas chromatograph (Agilent, 7890 model; Palo Alto, USA) equipped with a split/splitless injector, flame ionization detector (FID), and capillary column HP $5(30 \mathrm{~m} \times 0.32 \mathrm{~mm} \times 0.25 \mu \mathrm{m}$; J \& W Scientific, Folsom, USA). The conditions used were: injector temperature $220^{\circ} \mathrm{C}$; detector $250^{\circ} \mathrm{C}$, and oven $40^{\circ} \mathrm{C} / 1$ minute increasing $5{ }^{\circ} \mathrm{C} /$ minutes up to $110^{\circ} \mathrm{C}$ and $110^{\circ} \mathrm{C} / 5$ minutes, increasing $10^{\circ} \mathrm{C} /$ minute up to $250^{\circ} \mathrm{C}, 250^{\circ} \mathrm{C} / 10$ minutes. Helium was used as carrier gas at a flow rate of $1.0 \mathrm{~mL} /$ minute.

\subsection{Gas chromatography - mass spectrometry}

The volatile compounds were analyzed on a gas chromatograph (Varian, Saturn 2100D model; Walnut Creek, USA) equipped with a split/splitless injector and ion trap mass detector, ionization voltage of $70 \mathrm{eV}$, and capillary column CPSil 8CB low bleed MS $(30 \mathrm{~m} \times 0.25 \mathrm{~mm} \times 0.25 \mu \mathrm{m}$; Varian/ Chrompack, Middleburg, Netherlands) under the same chromatographic conditions previously described.
The Kovats indices of compounds, pure pattern coinjection and the comparison of the spectra reported in literature (KOTSERIDIS et al, 1999; KOTSERIDIS; BAUMES; SKOUROUMOUNIS, 1998; SÁNCHEZCONTRERAS; JIMÉNEZ; SANCHES, 2000; FERREIRA et al., 1998, 2008; SOMMERBURG et al., 2003; RODRÍGUEZBUSTAMANTE et al., 2005, 2006), and the NIST105 library (Standard Reference Data Program of the NATIONAL Institute of Standards and Technology) were used as additional data to confirm the compounds identity.

The Kovats indices for the compounds were obtained by co-injection with a hydrocarbon $\left(\mathrm{C}_{13}-\mathrm{C}_{16}\right)$ standard mixture (Sigma, St. Louis, USA) (KOVÁTS, 1958; van den DOOL; KRATZ, 1963; COLLINS; BRAGA; BONATO, 2006) and were compared with published data (SHALIT et al., 2001; DUQUE; OSORIO; MORALES, 2002; HÖGNADÓTTIR; ROUSEFF, 2003; ACREE; ARN, 2009; PHEROBASE, 2009).

\section{Results and discussion}

Eighty strains were selected from about 300 microorganisms according to the ability to degrade $\beta$-carotene dispersed in the agar plate. Of 80 microorganisms, 7 were selected by a nontrained panel composed by 5 members, who identified aromas of interest and intensities of aroma as "intensive aroma" or "very intensive aroma", as shown in Chart 1, after 72 hours of fermentation.

The selected microorganisms were isolated from fresh (CF) or dried (CS) marigold flowers (Calendula officinallis L.). The strains are CS1, a yeast; CF10, a filamentous fungus; and CS11, CS12, CS14, CF5, and CF9 are bacteria.

Charts 2 and 3 show the aroma descriptions after the $\beta$-carotene biotransformation produced by the 7 strains selected in the both cultures for 120 hours of fermentation.

The $\beta$-ionone, product of $\beta$-carotene degradation, was the main metabolite formed by all strains in both culture media. The identification of the compound was achieved by comparing the Kovats index (Chart 4) and the mass spectra present in the NIST105 database library or in the literature. The mass fragments $(\mathrm{m} / \mathrm{z})$ selected for the isomers of ionones were 69 , 177, and $192\left(\mathrm{M}^{+}\right)$.

Chart 2. Aroma descriptors for cultures without pre-inoculation.

\begin{tabular}{|c|c|c|c|c|c|c|c|}
\hline \multirow{2}{*}{$\begin{array}{l}\text { Time } \\
\text { (hours) }\end{array}$} & \multicolumn{7}{|c|}{ Microorganisms } \\
\hline & $\mathrm{CS} 1$ & CS11 & $\mathrm{CS} 12$ & CS14 & CF5 & CF9 & CF10 \\
\hline 24 & $\begin{array}{l}\text { Fruity, acid, } \\
\text { banana }\end{array}$ & $\begin{array}{l}\text { Fermented, } \\
\text { fruity }\end{array}$ & Banana & $\begin{array}{l}\text { Rotten fruit, } \\
\text { acid }\end{array}$ & Fermented & $\begin{array}{l}\text { Fermented, } \\
\text { fruity, orange }\end{array}$ & $\begin{array}{l}\text { Orange, } \\
\text { fruity }\end{array}$ \\
\hline 48 & $\begin{array}{l}\text { Fruity, sweet, acid, } \\
\text { ethyl acetate }\end{array}$ & Fruity, sweet & Fruity & Fruity & $\begin{array}{l}\text { Fruity, sweet, } \\
\text { acid }\end{array}$ & $\begin{array}{l}\text { Fermented, fruity, } \\
\text { sweet, acid }\end{array}$ & $\begin{array}{l}\text { Fermented, } \\
\text { fruity }\end{array}$ \\
\hline 72 & $\begin{array}{l}\text { Fruity, sweet, } \\
\text { solvent }\end{array}$ & $\begin{array}{l}\text { Rotten fruit, } \\
\text { yeast }\end{array}$ & $\begin{array}{l}\text { Fruity, acid, } \\
\text { cheese }\end{array}$ & $\begin{array}{l}\text { Solvent, stale } \\
\text { papaya }\end{array}$ & $\begin{array}{l}\text { Fruity, sweet, } \\
\text { acid, solvent }\end{array}$ & Yeast, orange & $\begin{array}{l}\text { Fermented, } \\
\text { sweet }\end{array}$ \\
\hline 96 & $\begin{array}{l}\text { Fruity, acid, } \\
\text { ethyl acetate }\end{array}$ & $\begin{array}{l}\text { Fruity, acid, } \\
\text { fermented }\end{array}$ & $\begin{array}{l}\text { Fruity, ethyl } \\
\text { acetate, acid }\end{array}$ & $\begin{array}{l}\text { Fruity, sweet, } \\
\text { acid, orange }\end{array}$ & Fruity, orange & $\begin{array}{l}\text { Fermented, } \\
\text { fruity }\end{array}$ & $\begin{array}{l}\text { Fermented, } \\
\text { fruity }\end{array}$ \\
\hline 120 & $\begin{array}{l}\text { Fruity, acid, } \\
\text { ethyl acetate }\end{array}$ & $\begin{array}{l}\text { Fermented, } \\
\text { sweet }\end{array}$ & $\begin{array}{l}\text { Fruity, sweet, } \\
\text { acid }\end{array}$ & $\begin{array}{l}\text { Orange, } \\
\text { chocolate }\end{array}$ & $\begin{array}{l}\text { Guaiacol, } \\
\text { medicament }\end{array}$ & $\begin{array}{l}\text { Fermented, } \\
\text { fruity }\end{array}$ & $\begin{array}{l}\text { Fermented, } \\
\text { fruity, sweet }\end{array}$ \\
\hline
\end{tabular}


The mass spectra published data for the $\beta$-ionone were 177 (FERREIRA et al., 2008; KOTSERIDIS et al, 1999; KOTSERIDIS; BAUMES; SKOUROUMOUNIS, 1998); 177, 161, 147 (FERREIRA et al., 1998); 192, 177, 162, 149, 135, 121, 105, 91 (SOMMERBURG et al., 2003) and 192, 177, 149, 135, 93, 91, 43, 41 (SÁNCHEZ-CONTRERAS; JIMÉNEZ; SANCHES, 2000; RODRÍGUEZ-BUSTAMANTE et al., 2005, 2006).

The $\beta$-ionone concentrations obtained for cultures without pre-inoculation ranged from 1.5 to $34.0 \mathrm{mg} . \mathrm{L}^{-1}$ (Figure $2 \mathrm{a}$ ). The strains CS1, CS11 and CF5 produced a higher concentration of metabolites when cultured this way. It is likekly that the addition of $\beta$-carotene to the cultures with pre-inoculation may have been harmful to microorganisms.

In cultures with pre-inoculation, the amount of compound produced ranged from 3.5 to $42.4 \mathrm{mg} . \mathrm{L}^{-1}$ (Figure $2 \mathrm{~b}$ ). The microorganisms CS12, CS14, CF9, and CF10 showed a higher $\beta$-ionone concentration in these cultures. It is likely that the increased cell mass facilitated the carotenoid degradation and the production of metabolites.

The highest concentrations of the compound were observed in the strains CS1 (34.0 mg. $\left.\mathrm{L}^{-1}\right)$ and CF9 (42.4 mg. $\left.\mathrm{L}^{-1}\right)$, at 72 and 24 hours of fermentation, cultured with and without preinoculation, respectively.

With regard to the fermentation time, the highest concentrations of $\beta$-ionone were obtained at 120 hours of fermentation for most strains cultured without pre-inoculation. In cultures with pre-inoculation, increased metabolite production was observed at 24 hours of fermentation.

Zorn et al. (2003a) observed that $\beta$-ionone was the main metabolite derived from $\beta$-carotene. That compound was formed in mycelium free culture media of Ischnoderma benzoinum (8 mol\%), Marasmius scorodonius ( $8 \mathrm{~mol} \%)$, and
Trametes vesicolor (10 mol\%). Other products from $\beta$-carotene degradation such as $\beta$-cyclocitral, dihydroactinidiolide and 2-hydroxy-2,6,6-trimethylciclohexanone were also found.

In another study, Zorn et al. (2003b) detected that $\beta$-ionone as the main metabolite was formed in mycelium free medium of Lepista Irina by using $\beta$-carotene as a substrate for the reaction. The highest concentration observed was of $12 \mathrm{~mol} \%$ after 1 hour of reaction. The presence of $\beta$-cyclocitral, dihydroactinidiolide, and 2-hydroxy-2,6,6-trimethylcyclohexanone was observed as well.

The capacity to produce $\beta$-ionone from lutein was investigated by Maldonado-Robledo et al. (2003). Geotrichum sp presented the highest production of $\beta$-ionone of $4.5 \mathrm{mg} . \mathrm{L}^{-1}$ at 48 hours of incubation, converting it into 7,8 -dihydro- $\beta$-ionone and 7,8-dihydro- $\beta$-ionol. A mixed culture formed by Bacillus sp. and Geotrichum sp. produced $2 \mathrm{mg} . \mathrm{L}^{-1}$ of the compound at 24 hours of fermentation.

$\beta$-Ionone is an aroma compound widely used in aroma and fragrance industries for its floral, fruity and sweet aromas. It is generated by direct cleavage of $\beta$-carotene, which occurs in plants, fruits and flowers rich in carotenoids (KOTSERIDIS et al., 1999; FLEISCHMANN; WATANABE; WINTERHALTER, 2003; ZORN et al., 2003a, 2003b; SINKIN et al., 2004; IBDAH et al., 2006; TIEMAN et al., 2006; WACHÉ; BOSSER-DERATULD; BELIN, 2006).

$\beta$-Damascone and pseudoionone were formed at low concentrations. For the $\beta$-damascone, the highest concentrations were observed in the strains CS1 $\left(6.7 \mathrm{mg} . \mathrm{L}^{-1}\right)$ and CF9 (4.0 mg. $\left.\mathrm{L}^{-1}\right)$, at 72 hours without pre-inoculation and 24 hours with pre-inoculation, respectively. Pseudoionone was formed in most concentrations by the strains CS1 (12.4 mg. $\mathrm{L}^{-1}$ with) and CS14 (11.6 mg. $\left.\mathrm{L}^{-1}\right)$, at 72 and 48 hours of fermentation in cultures with and without pre-inoculation.

Chart 3. Aroma descriptors for cultures with pre-inoculation.

\begin{tabular}{|c|c|c|c|c|c|c|c|}
\hline \multirow{2}{*}{$\begin{array}{l}\text { Time } \\
\text { (hours) }\end{array}$} & \multicolumn{7}{|c|}{ Microorganisms } \\
\hline & CS1 & CS11 & CS12 & CS14 & CF5 & CF9 & CF10 \\
\hline 24 & $\begin{array}{l}\text { Fermented, } \\
\text { sour fruit, rotten }\end{array}$ & Fermented, sweet & $\begin{array}{l}\text { Acid, vinegar, } \\
\text { solvent }\end{array}$ & $\begin{array}{l}\text { Fruity, sweet, acid, } \\
\text { orange }\end{array}$ & $\begin{array}{l}\text { Fermented, } \\
\text { humid cloth }\end{array}$ & $\begin{array}{l}\text { Fermented, fruity, } \\
\text { sweet, humid cloth }\end{array}$ & $\begin{array}{l}\text { Rotten fruit, bad, } \\
\text { sour }\end{array}$ \\
\hline 48 & $\begin{array}{l}\text { Fruity, acid fruit, } \\
\text { acid }\end{array}$ & Fruity, sweet, acid & $\begin{array}{l}\text { Acid, sour, } \\
\text { stale fruit }\end{array}$ & $\begin{array}{l}\text { Fruity, fermented, } \\
\text { acid, sweet }\end{array}$ & Fruity, sweet, tea & $\begin{array}{l}\text { Fermented, fruity, } \\
\text { sweet }\end{array}$ & Fruity, wet cloth \\
\hline 72 & Fruity, sweet & Fermented & Sour, rotten fruit & $\begin{array}{l}\text { Fruity, sweet, apple, } \\
\text { acid }\end{array}$ & Fruity, sweet, acid & Fermented, fruity & Fermented, orange \\
\hline 96 & $\begin{array}{l}\text { Fruity, sour, } \\
\text { acid fruit }\end{array}$ & $\begin{array}{l}\text { Fruity, sweet, } \\
\text { acid, ethyl acetate }\end{array}$ & Acid, sour & $\begin{array}{l}\text { Fermented, fruity, } \\
\text { sweet, acid }\end{array}$ & Green & Fermented & $\begin{array}{l}\text { Fermented, bad, } \\
\text { rotten }\end{array}$ \\
\hline 120 & $\begin{array}{l}\text { Acid fruit, sour, } \\
\text { rotten }\end{array}$ & $\begin{array}{l}\text { Fruity, sweet, } \\
\text { acid, sour }\end{array}$ & $\begin{array}{l}\text { Sour, acid, } \\
\text { rotten fruit }\end{array}$ & $\begin{array}{l}\text { Fermented, bread, } \\
\text { orange }\end{array}$ & $\begin{array}{l}\text { Bad, rotten, acid, } \\
\text { humid cloth }\end{array}$ & Fermented & $\begin{array}{l}\text { Fruity, acid, } \\
\text { alcoholic }\end{array}$ \\
\hline
\end{tabular}

Chart 4. Kovats indices obtained for the compounds.

\begin{tabular}{|lcll|}
\hline \multicolumn{1}{|c}{ Compound } & Experimental $^{\mathrm{a}}$ & \multicolumn{1}{c|}{ Reference $^{\mathrm{b}}$} \\
\hline$\beta$-Damascone & 1424 & 1410 & (ACREE; ARN, 2009) \\
$\beta$-Ionone & & 1415 & (PHEROBASE, 2009) \\
& 1496 & 1493 & (SHALIT et al., 2001; ACREE; ARN, 2009) \\
& & 1494 & (HÖGNADÓTTIR; ROUSEFF, 2003; PHEROBASE, 2009) \\
Pseudoionone & & 1497 & (DUQUE; OSORIO; MORALES, 2002) \\
\hline
\end{tabular}

${ }^{\mathrm{a} C}$ Column HP5; ${ }^{\mathrm{b} C o l u m n}$ HP5/DB5/CP-Sil 8CB; ${ }^{\mathrm{c} C o l u m n ~ O V-3 ~}$ 

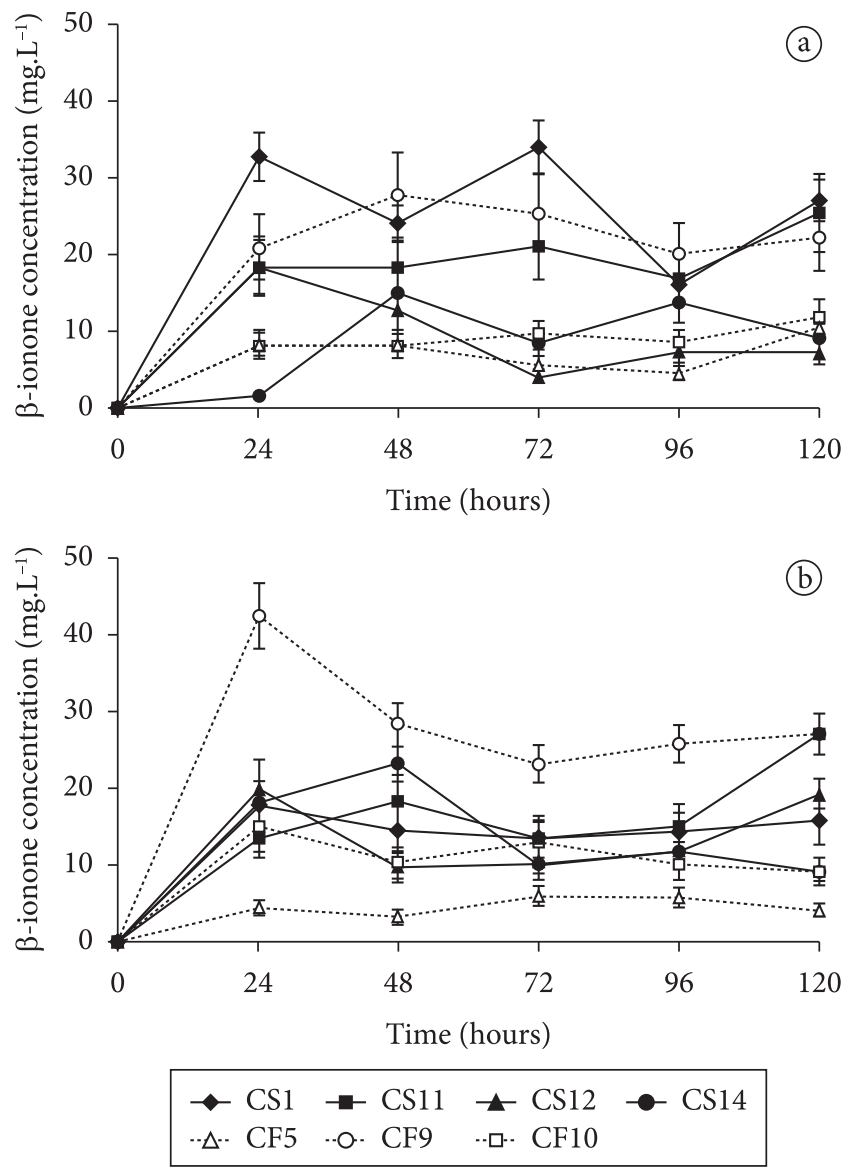

Figure 2. The $\beta$-ionone concentration during 120 hours of fermentation for the strains cultured a) without; and b) with pre-inoculation.

$\beta$-Ionone and pseudoionone (6,10-dimethyl-3,5,9undecatrien-2-one) are compounds present in low concentrations but with strong effects on the human general perception (SIMKIN et al., 2004).

The compound TTN was tentatively identified by mass spectrometry and a comparison with a mass spectral the database library. However, it was not quantified. Apocarotenoids apparently derived from the cleavage of the inner part of the $\beta$-carotene. They were identified in the mass spectra but could not be identified (standards unavailable)

Apocarotenoids are compounds that derive from the cleavage of carotenoids and include aroma compounds. Their diversity results from the great number of carotenoid precursors, variability of sites of cleavage, and subsequent modifications (SCHWARTZ; QIN; ZEEVAART, 2001; IBDAH et al., 2006).

\section{Conclusions}

C-13 ionones and derivatives are widely distributed in nature. They are important constituents of essential vegetal oils and contribute especially to the aromatic profile and to fruit and flower fragrances. Among the ionones, $\beta$-ionone is a compound that comes from $\beta$-carotene rupture.

These microorganisms demonstrate potential for the production of aroma compounds, i.e., the production of aroma compounds through a microbiological process should be explored. The strains studied showed biocatalysis capacity for the production of volatile compounds from $\beta$-carotene.

The $\beta$-carotene cleavage by microorganisms produces $\beta$-ionone and other compounds. Other compounds may have been formed, but they could not be identified. Other techniques for the identification and identity confirmation may be used to help in the elucidation of structures and compounds that are present in the extracts obtained.

New strategies for natural flavor biogeneration are likely to be developed in the future and will certainly be an alternative to the production of such compounds. The consumers' increasing demand for natural products has intensified the production of these compounds via biotechnology.

\section{Acknowledgements}

The authors are grateful for the financial support provided by CNPq.

\section{References}

ACREE, T.; ARN, H. Flavornet and human odor space. Disponível em: <http://www.flavornet.org >. Acesso em: 1 fev. 2009.

BALDERMANN, S.; NAIM, M.; FLEISCHMANN, P. Enzymatic carotenoid degradation and aroma formation in nectarines (Prunus persica). Food Research International, v. 38, n. 8-9, p. 833-836, 2005.

BUTTERY, R. G. et al. Quantitative and sensory studies on tomato paste volatiles. Journal of Agricultural and Food Chemistry, v. 38, n. 1, p. 336-340, 1990.

COLlinS, C. H.; BRAGA, G. L.; BONATO, P. S. Fundamentos de cromatografia. Campinas: Unicamp, 2006.

DUQUE, C.; OSORIO, C.; MORALES, A. L. $\mathrm{C}_{13}$-noroisoprenoids in the aroma of colombian tropical fruits. In: WINTERHALTER, P.; ROUSEFF, R. L. Carotenoid-derived aroma compounds. Washington, DC: American Chemical Society, 2002, p. 194-205.

FERREIRA, A. C. S. et al. Study of major aromatic compounds in port wines from carotenoid degradation. Food Chemistry, v. 110, n. 1, p. 83-87, 2008.

FERREIRA, V. et al. Quantitative determination of trace and ultratrace flavour active compounds in red wines through gas chromatographicion trap mass spectrometric analysis of microextracts. Journal of Chromatography A, v. 806, n. 2, p. 349-354, 1998.

FLEISCHMANN, P.; WATANABE, N.; WINTERHALTER, P. Enzymatic carotenoid cleavage in star fruit (Averrhoa carambola). Phytochemistry, v. 63, n. 2, p. 131-137, 2003.

HÖGNADÓTTIR, Á.; ROUSEFF, R. L. Identification of aroma active compounds in orange essence oil using gas chromatographyolfactometry and gas chromatography-mass spectrometry. Journal of Chromatography A, v. 998, n. 1-2, p. 201-211, 2003.

IBDAH, M. et al. Functional characterization of $C m C C D 1$, a carotenoid cleavage dioxygenase from melon. Phytochemistry, v. 67, n. 15, p. 579-1589, 2006.

KOTSERIDIS, Y. et al. Quantitative determination of $\beta$-ionone in red wines and grapes of Bordeaux using a stable isotope dilutwion assay. Journal of Chromotography A, v. 848, n. 1-2, p. 317-325, 1999.

KOTSERIDIS, Y.; BAUMES, R.; SKOUROUMOUNIS, G. K. Synthesis of labeled $\left[{ }^{2} \mathrm{H}_{2}\right] 2$-methoxy-3-isobutylpyrazine, $\left[{ }^{2} \mathrm{H}_{3}\right] \mathrm{a}$-ionone, 
and $\left[{ }^{2} \mathrm{H}_{3}\right] \beta$-ionone, for quantification in grapes, juices and wines. Journal of Chromatography A, v. 824, n. 1, 71-78, 1998.

KOVÁTS, E. Gas-chromatographische charakterisierung organisher verbindungen. Helvetica Chimica Acta, v. 41, n. 206, p. 1915- 932, 1958.

MALDONADO-ROBLEDO, G. et al. Production of tobacco aroma from lutein. Specific role of the microorganisms involved in the process. Applied Microbiology and Biotechnology, v. 62, n. 5-6, p. 484-488, 2003.

PHEROBASE. Database of pheromones and semiochemicals. Disponível em: <http://www.pherobase.com/database/kovats/ kovats-index.php>. Acesso em: 1 fev. 2009.

RODRÍGUEZ-BUSTAMANTE, E. et al. Bioconversion of lutein using a microbial mixture - maximizing the production of tobacco aroma compounds by manipulation of culture medium. Applied Microbiology and Biotechnology, v. 68, n. 2, p. 174-182, 2005.

RODRÍGUEZ-BUSTAMANTE, E. et al. Novel method for aroma recovery from the bioconversion of lutein to ionone by Thricosporon asahii using a mesoporous silicate material. Applied Microbiology and Biotechnology, v. 71, n. 4, p. 568-573, 2006.

SÁNCHEZ-CONTRERAS, A.; JIMÉNEZ, M.; SANCHES, S. Bioconversion of lutein to products with aroma. Applied Microbiology and Biotechnology, v. 54, n. 4, p. 528-534, 2000.

SCHWARTZ, S. H.; QIN, X.; ZEEVAART, J. A. D. Characterization of a novel carotenoid cleavage dioxigenase from plants. The Journal of Biological Chemistry, v. 276, n. 27, p. 25208-25211, 2001.

SHALIT, M. et al. Acetyl-CoA: alcohol acetyltransferase activity and aroma formation in ripening melon fruits. Journal of Agricultural and Food Chemistry, v. 49, n. 2, p. 794-799, 2001.

SHIMONI, E. et al. Biotransformation ofpropenybenzenes by an Arthrobacter sp. and its $t$-anethole blocked mutants. Journal of Biotechnology, v. 105, n. 1-2, p. 61-70, 2003.

SIMKIN, A. J. et al. The tomato carotenoid cleavage dioxygenase 1 genes contribute to the formation of the flavor volatiles - ionone, pseudoionone, and geranylacetone. The Plant Journal, v. 40, n. 6, p. 882-892, 2004.
SOLÍS-SOLÍS, H. M. et al. Characterization of aroma potential of apricot varieties using different extraction techniques. Food Chemistry, v. 105, n. 2, p. 829-837, 2007.

SOMMERBURG, O. et al. Carotene cleavage products after oxidation mediated by hypochlorous acid - a model for neutrophil-derived degradation. Free Radical Biology and Medicine, v. 35, n. 11, p. 1480-1490, 2003.

TIEMAN, D. M. et al. Identification of loci affecting flavor volatile emissions in tomato fruits. Journal of Experimental Botany, v. 57, n. 4, p. 887-896, 2006.

UENOJO, M.; MARÓSTICA JÚNIOR, M. R.; PASTORE, G. M. Carotenóides: propriedades, aplicações e biotransformação para formação de compostos de aroma. Química Nova, v. 30, n. 2, p. 616-622, 2007.

van den DOOL, H.; KRATZ, P. C. A generalization of the retention index system including linear temperature programmed gas-liquid partition chromatography. Journal of Chromatography, v. 11, n. 2, p. 463-471, 1963.

WACHÉ, Y. et al. Effect of cis/trans isomerism of carotene on the ratios of volatile compounds produced during oxidative degradation. Journal of Agriculture and Food Chemistry, v. 51, n. 7, p. 1984-1987, 2003.

WACHÉ, Y.; BOSSER-DERATULD, A.; BELIN, J. M. Dispersion of carotene in process of production of ionone by cooxidation using enzyme-generated reactive oxygen species. Process Biochemistry, v. 41, n. 11, p. 2337-2341, 2006.

WINTERHALTER, P.; ROUSEFF, R. Carotenoid-derived aroma compounds: an introduction. In: WINTERHALTER, P.; ROUSEFF, R. L. Carotenoid-Derived Aroma Compounds. Washington, DC: American Chemical Society, 2002. p. 1-17.

ZORN, $H$. et al. Cleavage of $\beta, \beta$-carotene to flavor compounds by fungi. Applied Microbiology and Biotechnology, v. 62, n. 4, p. 331-336, 2003a.

ZORN, H. et al. A peroxidase from Lepsita irina cleaves $\beta, \beta$-carotene to flavor compounds. Biological Chemistry, v. 384, n. 7, p. 1049-1056, 2003b. 